\title{
Erratum to: Lessons from basic pancreatic beta cell research in type-2 diabetes and vascular complications
}

\author{
Lena Eliasson $^{1} \cdot$ Jonathan Lou S. Esguerra $^{1} \cdot$ Anna Wendt $^{1}$
}

Published online: 14 February 2017

(c) The Japan Diabetes Society 2017

\section{Erratum to: Diabetol Int}

DOI 10.1007/s13340-017-0304-4

Owing to an unfortunate mistake at the typesetter end, the text including the subheading "Statins and insulin sensitivity" was transposed incorrectly under the heading "Beta cell insulin secretion and exocytosis". It should be under the heading "Impact on insulin secretion and glucose homeostasis by statins".

The original article was corrected.

The online version of the original article can be found under doi:10.1007/s13340-017-0304-4.

Lena Eliasson

lena.eliasson@med.lu.se

Islet Cell Exocytosis, Department of Clinical Sciences

Malmö, Lund University Diabetes Centre, Lund University,

Clinical Research Centre, SUS 91-11, Box 50332,

20213 Malmö, Sweden 